\title{
中間水分肉の製造工程におけるタンパク質の変化
}

\author{
六車三治男* ・上田洋子*・安田郁博* \\ 中村豊郎**・沼田正寛**
}

\author{
Changes of Proteins in Intermediate Moisture Meats \\ during the Processing of Products \\ (Studies on Factors Related to the Properties of \\ Intermediate Moisture Meats Part I) \\ Michio Muguruma*, Yoko Ueda*, Ikuhiro Yasuda*, \\ Toyoo NaKamura** and Masahiro Numata** \\ * Department of Animal Science, Faculty of Agriculture, Kyushu \\ University, Hakozaki, Fukuoka 812 \\ ** Central Research Institute, Ito Ham Foods Inc., Meguro-ku, Tokyo 143
}

\begin{abstract}
Intermediate moisture meats were manufactured from porcine loin using commercial procedures and with varying levels $(2 \%, 4 \%, 6 \%, 8 \%, 10 \%)$ of $\mathrm{NaCl}$. To study the changes of proteins in intermediate moisture meats, water activity, moisture content, salt concentration and extractability of proteins were investigated during curing and smoking. During the process of curing, the salt concentration in meat increased while the moisture content and water activity decreased. These changes were very rapid in the first 3 days of curing. The product, which was cured for 9 days, has been subjected to smoking $\left(15^{\circ} \sim 20^{\circ} \mathrm{C}\right)$. As a result the water activity decreased rapidly. The extractability of proteins has been observed at the same time. SDS-PAGE shows that changes in extractability of water soluble proteins are less noticeable while the extractability of structural proteins depended on curing and smoking period. SDS-PAGE shows that the extractability of myosin decreased with increasing curing and smoking period. Changes in extractability of actin, tropomyosin and $\alpha$-actinin seem to be not much. Electron micrographic observations show that even after 9 days of curing the typical ultrastructure of the myofibrils is clearly visible. But when cured meat is smoked for 4 days, the structure of the thick filament and $Z$-line appears to be under-going disorganization. After 8 days of smoking the structure of muscle has undergone a greater degree of disorganization. However, the actin filaments are still organized. (Received Jun. 1, 1985)
\end{abstract}

近年中間水分食品に関する研究が多くなされてはいる

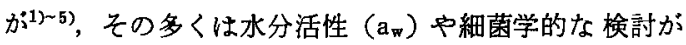
主なるのであり，中間水分肉を構成するタンパク質の質 的変化についての検討は見られない，近年，生産が解禁 された非加熱食肉製品である生八ムも中間水分肉の一種 と見なされる．そこで中間水分肉の性質に関与する諸因 子に関する研究を行う第一歩として, 生八ムの製造工程
に扎ける水分含量, $\mathrm{a}_{\mathrm{w}}$ ，食塩濃度， $\mathrm{pH}$ ，筋肉構造タンパ ク質の抽出性ならびに筋肉の形態的変化等について検討 した. また食塩濃度の变化による塩漬肉の状態変化につ いてる検討したので併せて報告する。

$$
\text { 実 験 方 法 }
$$

\section{1. 実験材料}

† 中間水分肉の性質に関与する諸因子に関する研究（第 1 報）

*九州大学農学部 (T812 福岡市東区箱崎 6-10-1)

**伊藤八厶株式会社中央研究所（广153 東京都目黒区三田 1-6-21） 
生八ムの製造は豚肉ロース部位を原料とした。塩漬は 食塩, 砂糖, アスコルビン酸ナトリウム, 硝酸カリウム, 亜硝酸ナトリウムを原料肉に対しそれぞれ 6, $1,0.1$, $0.05 ， 0.03 \%$ になるよ5に添加し暲塩法により行った. 冷くん㖶は塩漬終了後の試料を 3 段階のスケジュールに 従い行った。すなわら第 1 段階は温度 $20^{\circ} \mathrm{C}$ ，湿度 $90 \%$ で48 時間, 第 2 段階は温度 $18^{\circ} \mathrm{C}$, 湿度 $88 \%$ で 32 時間, 第 3 段階は温度 $15^{\circ} \mathrm{C}$ ，湿度 $82 \%$ で適当な まで乾燥した：〈ん煙は第 1 段階 20 時間後 20 分間，さ らに第 1，第 2 段階終了時にそれぞれ 10 分間行った. 食 塩濃度の異なる塩漬肉の調製にはと殺後約 18 時間経過 した豚肉ロース部位を原料として用いた. 塩潰はフスコ ルビン酸ナトリウム, 硝酸カリウム, 亜硝酸ナトリウム を原料肉に対しそれぞれ $0.1 ， 0.05 ， 0.03 \%$ になるよら に添加し，食塩を 2，4，6，8，10\% と添加量を变え， 乾塩法により $4^{\circ} \mathrm{C}$ で 14 日間行った.

\section{2. 一般分析法}

水分含量, $\mathrm{pH}$ 測定および食塩濃度の定量は KoNIECKo

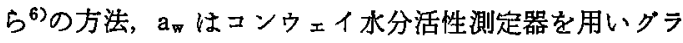
フ择入法により求めた。

\section{3. 塩清肉および冷くん肉からのタンパク質の抽出性 の定量}

試料からのタンパク質の抽出性は次の 3 種類の溶液に より求めた. (1) SSS-溶液 ( $25 \mathrm{mM} \mathrm{KCl}, 20 \mathrm{mM} \mathrm{K}$-phosphate, $2 \mathrm{mM} \mathrm{MgCl}_{2}, 2 \mathrm{mM}$ EGTA, $1 \mathrm{mM} \mathrm{NaN}_{8}, \mathrm{pH}$ 6.9) (2) HS-溶液 ( $0.6 \mathrm{M} \mathrm{KCl}, 0.1 \mathrm{M} \mathrm{K}$-phosphate, $10 \mathrm{mM}$ sodium pyrophosphate, $1 \mathrm{mM} \mathrm{MgCl}_{2}, \mathrm{pH}$ 6. 4) (3) KI-溶液 (0.6 M KI, $6 \mathrm{mM}$ sodium thiosulfate, 2
$\mathrm{mM} \beta$-mercaptoethanol, $0.5 \mathrm{mM}$ ATP, $20 \mathrm{mM}$ Trisacetate, $\mathrm{pH} 7.5$ ). 試料のひき肉 $10 \mathrm{~g}$ K対し各種上記溶 液をそれぞれ 5 倍量添加，ホモジナイズ後 $0^{\circ} \mathrm{C}$ で 10 分 間静置した． $10000 \times \mathrm{g}$ で 10 分間遠心分離啳, 得られた 上清のタンパク質濃度をミクロケルダール法により標準 化したビウレット法7により定量した。

\section{4. 電気泳動}

ドデシル硫酸ナトリウムーポリアクリルアミドゲル電 気泳動 (SDS-PAGE) は LAEMMLI の方法8)によって行 った. スラブ型の泳動装置により,フクリルアミドの濃 度は 7.5〜17.5\% のグラジェントゲルを用いた。

\section{5. 電子顕微鏡による観察}

9 日間塩漬後と冷くん㖶 4 およ゙゙ 8 日目の豚ロース筋 肉を常法に上って超薄切片とし, 日立 $\mathrm{H}-300 \mathrm{~S}$ 型電子顕 微鏡により観察した.

\section{実験結果および考察}

\section{1. 生ハムの製造工程中における食肉の状態变化} 生八ムの製造工程中に批ける水分含量, $\mathrm{a}_{w}$, 食塩濃度, $\mathrm{pH}$ 等の変化を Fig. 1 に示す. 塩漬に伴って水分含量,

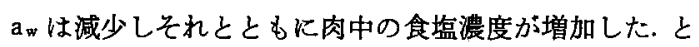
くにこれらの現象は塩漬 3 日目むでが顕著であり，乾塩 法により原料肉に対して重量比で $6 \%$ になるように添加 した食塩は，その時点で $4.2 \%$ の含有量を示した. その 後塩漬 9 日目までは $a_{w}$ 低下と食塩濃度の増加の程度は ゆるやかであった．塩漬終了時に $a_{w}$ は 0.952 , 食塩濃度 は $5.3 \%$ になった. 一方, 肉の $\mathrm{pH}$ には大きな变化は見 られなかった．次に 9 日間の塩漬終了後の試料を 8 日間

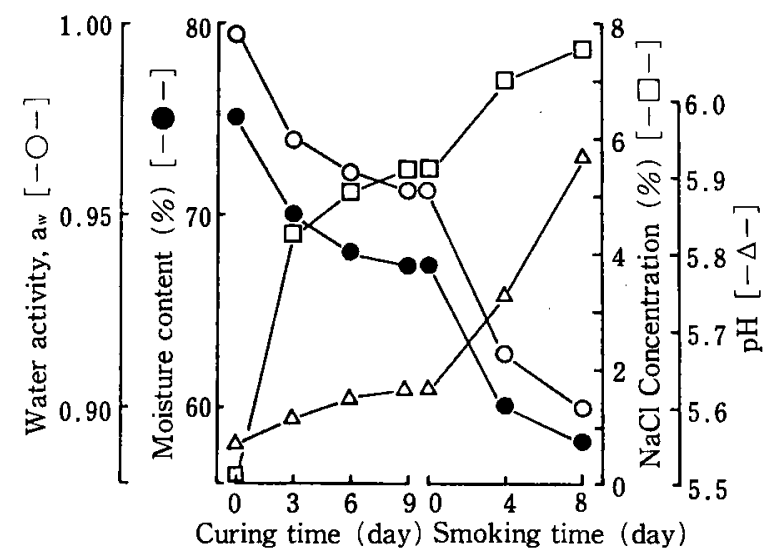

Fig. 1 Changes in water activity, moisture content, $\mathrm{NaCl}$ concentration and $\mathrm{pH}$ of meat during and smoking period 
冷くん煙を行った，その結果，くん煙 4 日目までは急速 に水分含量， $a_{w}$ ともに同様の傾向で低下した，一方，食 塩含量はそれとともに增加した。こ机らの傾向はくん煙

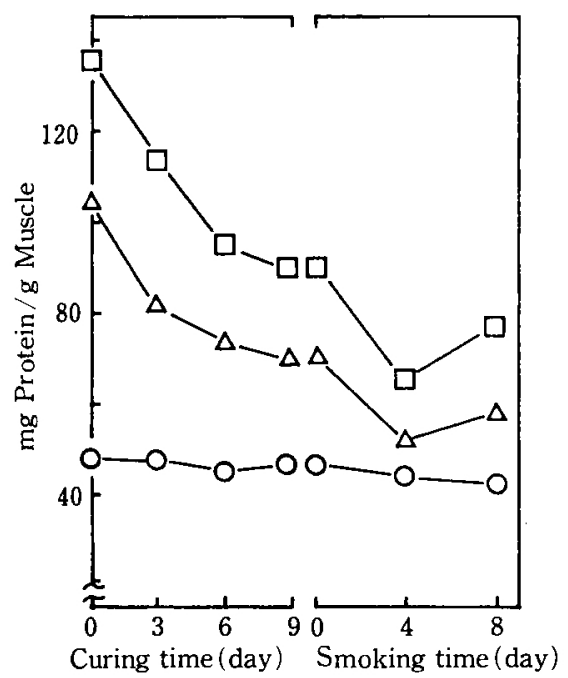

Fig. 2 Comparison of amounts of protein extracted from meat with different kinds of solution during curing and smoking period

o--o, SSS-solution; $\Delta-\Delta$, HS-solution;

$\square-\square$, KI-solution
4 日目から8日目むではやゆるかであった。

次に筋肉タンパク質の抽出性の変化を SSS, HS, KI の3 種類の溶液を用いて検討した（Fig. 2)，SSS-溶液 は筋原線維を調製する際に使用する溶液であり，この溶 液では筋肉の水溶性タンパク質が抽出されてくる.HS溶液は筋肉の構造タンパク質であるミオンンを主として 抽出し，KI一溶液はアクチンフィラメントに存在する Fアクチンを G-化することにより，主にアクチンを抽出 する溶液と考えられている。これら 3 種類の溶液を用い て検討した結果, SSS一溶液により抽出されてくる水溶 性タンパク質には, 塩漬, 冷くん煙它通じて量的に大き な変化は認められなかった. しかしながら HS-溶液, KI-溶液により抽出されてくる筋肉中の塩溶性タンパク 質の量は塩漬の進行に伴い減少した．この傾向は Fig. 1 に示した a の值の変化に対応する傾向が認められた。 冷くん 4 日目までは抽出量はさらに低下したが，その後 8日目になると若干增加する傾向が見られた. 3 種類の 抽出溶液により抽出されてきたタンパク質成分の分子種 を検討するために SDS-PAGE を行った. Fig. 3-a か ら明らかなよらに，抽出されてきた水溶珄タンパク質に はその抽出量と同様大きな変化は認められなかった。 し かしながら，HS-溶液による溶出では分子量 200000 ダ ルトンのミオンン重鎖の量が塩漬や冷くん4日目まで awと同様の傾向で減少することが明らかとなった (Fig.

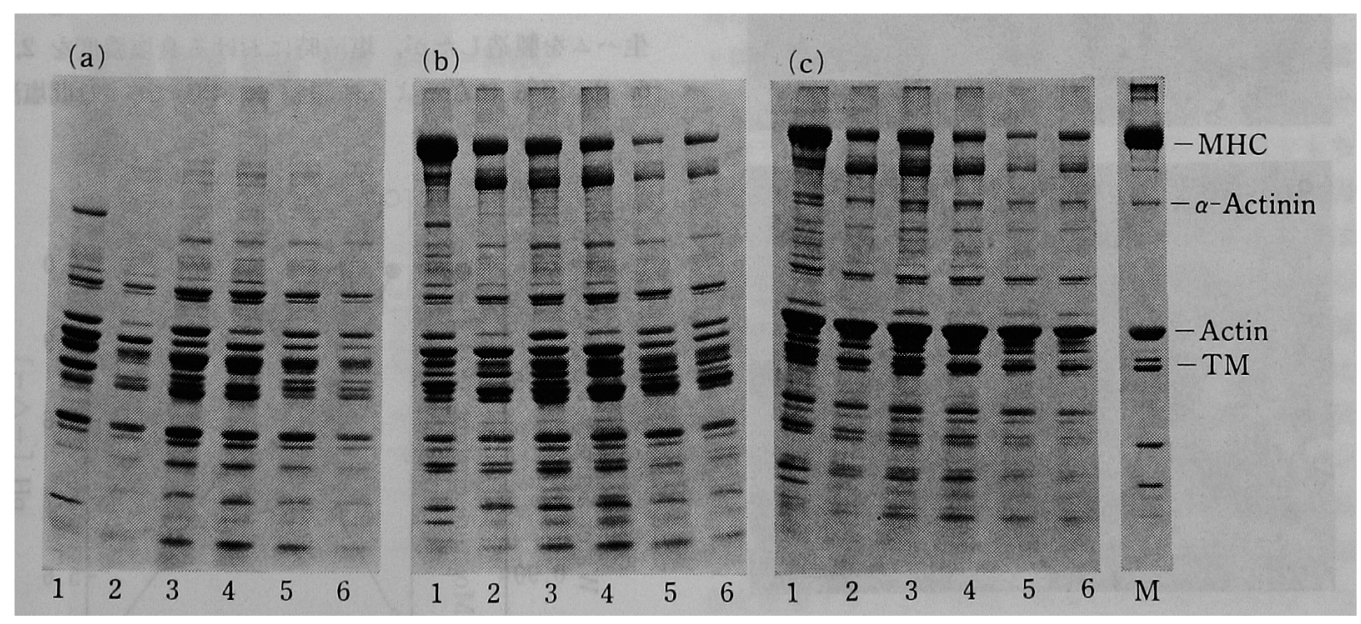

Fig. 3 SDS-polyacrylamide gel (7.5 17.5\%) electrophoretic pattern of proteins extracted from cured meat with different kinds of solution

(a), SSS-solution; (b), HS-solution; (c), KI-solution; 1, control; 2, cured for 3 days; 3 , cured for 6 days; 4 , cured for 9 days; 5 , cured for 9 days and smoked for 4 days; 6 cured for 9 days and smoked for 8 days; M, myofibrillar protein standard; MHC, myosin heary chain; TM, tropomyosin. The molecular weights of MHC, n-actinin, actin and TM are $200 \mathrm{kd}, 100 \mathrm{kd}, 42 \mathrm{kd}$ and $34 \mathrm{kd}$, respectively. 
3-b). 冷くん4 日目から8 日目で HS-容液による抽出 量が若干增加したがこの增加はミオンンに起因すること か SDS-PAGE の結果からも明らかである. KI-溶液に よる抽出ではつクチン以外にミオンンも抽出されてくる が，この現象はおそらく KI-溶液に上り抽出されてくる ミオシンがその一部を占めているためと思われる (Fig. 3-c). HS-容液により抽出されてきた成分扰よび KI-

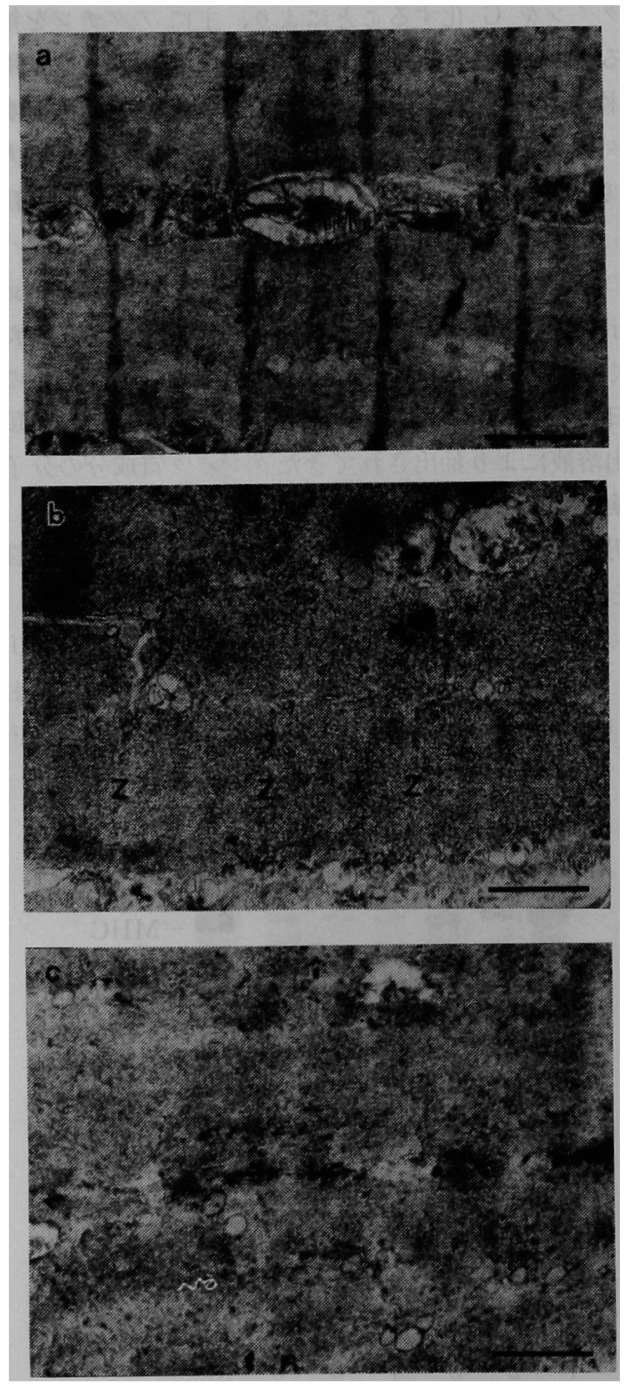

Fig. 4 Electron micrographs of cured or/and smokod meat

(a). cured for 9 days; (b), cured for 9 days and smokod for 4 days; (c), cured for 9 days and smoked for 8 days; Z, Z-line; magnification, $\times 28000$. The calibration bar equals $1 \mu \mathrm{m}$.
溶液により抽出されてきた成分の SDS-PAGE パターン には水溶性タンパク質も含有されていると考えられる が，KI-溶液による抽出では筋原線維の細いフィラメン トを構成しているアクチンやトロポミオシンに大きな変 化仕梕められなかった．また $Z$ 線の構成成分である $\alpha$ フクチニンにるその抽出パターンに顕著な差はなかっ た.

Fig. 4 は塩漬,冾くんによる筋肉の徽細構造を示した ものである. 9 日間塩漬終了後の筋肉ではその筋原線維 の基本的構造は明瞭に保持されている（Fig. 4-a). 乙 かし，冷くん4日目になると主にミオシンから構成され ている太い>ィラメントや Z 線の微細構造がだんだん 之不明瞭飞崩壊していく傾向が喼められた (Fig. 4-b). さらに令くん8日目の生八厶最終鉒品ではその㑯向がさ らに顕著になり，細いフィラィント以外の構造に規則性 が観察されにくくなった．また筋原線維全体にミオンン の塊の様な構造が観察されるよらになった (Fig. 4-c). SDS-PAGE の結果之電顕の結果から硆くん煙による $\mathrm{a}_{\boldsymbol{N}}$ の低下とそれに伴与食塩濃度の增加や，さらには冷くん 中に打ける 15 20 $0^{\circ} \mathrm{C}$ の温度条件等によって，ミオシン より構成されている太いフィラメントに構造の崩裟や構 成タンパク質の状態变化が生ずることが明らかになっ た.

\section{2. 食塩瀑度の変化による塩清肉の状態変化}

前項では塩漬時に和ける食塩濃度を $6 \%$ と一定にして 生八厶を製造したが，塩漬時に於ける食塩涱度を $2 ， 4$ ， $6 ， 8 ， 10 \%$ となるようと調整し， $4{ }^{\circ} \mathrm{C}$ で 14 日間塩漬 し

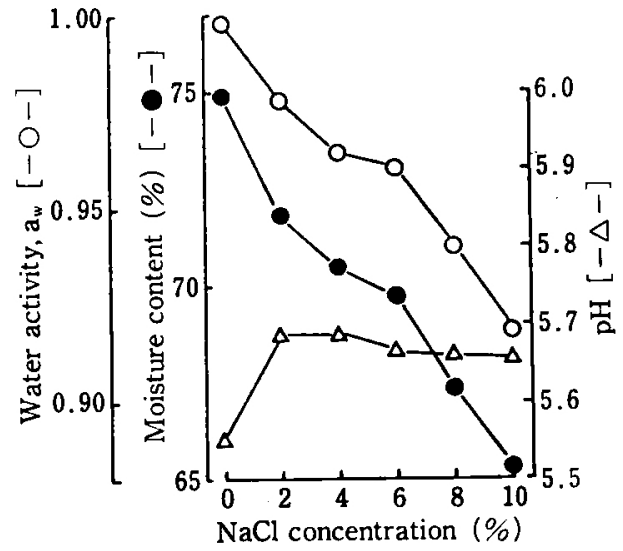

Fig. 5 Effects of salt concentration on water activity, moisture content and $\mathrm{pH}$ of cured meat during storage at $4^{\circ} \mathrm{C}$ for 14 days 
た肉について水分含量, $\mathrm{a}_{\mathrm{w}}, \mathrm{pH}$ の变化を測定した（Fig. 5). その結果, 食塩濃度が増加寸るにつれ水分含量, $a_{w}$ ともに低下した：この傾向は 0〜 4\%, 6〜10\%の筙用で 急速であり，4〜6\% では僅かではあるがそれらの低下

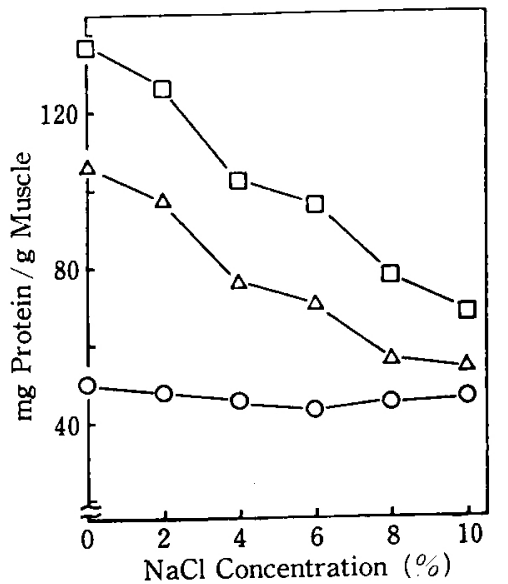

Fig. 6 Comparison of amounts of protein extracted from meat cured at different salt concentrations and stored at $4^{\circ} \mathrm{C}$ for 10 days with different kinds of solution o-o, SSS-solution; $\Delta-\Delta$, HS-solution; $\square-\square$, KI-solution.

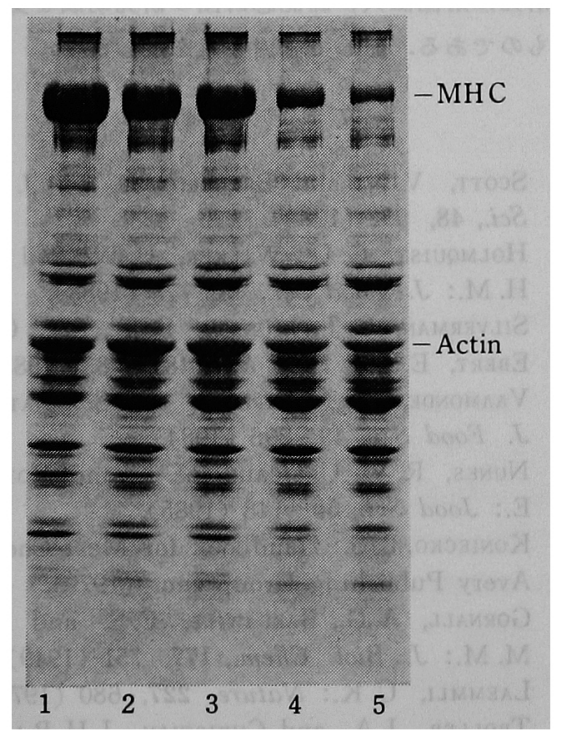

Fig. 7 SDS-polyacrylamide gel $(7.5 \sim 17.5 \%)$ electrophoretic pattern of proteins ex. tracted from meat cured at different salt concentrations with HS-solution

$1,2 \% ; 2,4 \% ; 3,6 \% ; 4,8 \% ; 5,10 \%$.
はゆるやかであった。な技察に肉中の食塩含量を測定 した結果では表示した濃度よりは僅かながら少なかっ た.

タンパク質の抽出量を測定してみると水溶性タンパク 質の抽出量に及ぼす塩漬時の食塩濃度の影響は見られな かったが，HS一溶液とKI-溶液により抽出されてくるタ ンパク質量は食塩濃度の増加に伴って減少した（Fig. 6).さらに HS-溶液により抽出されてきたタンパク質 成分の分子種を SDS-PAGE で求めたところ, 食塩濃度 の増加によってミオシンが抽出されにくくなることが明 瞭になった（Fig，7).

現在， $a_{w}$ は全水分含量よりむ食品の物理的, 化学的, 生物学的特性に密接に関係があることが認められてい る9?. 食品の保存性を高めるのには様々な方法がある が，薬剂 (水分活性調節剂) の使用によってその $\mathrm{a}_{w}$ を下 げることも一方法である゙．食肉に限らず食品一般にお いて食塩添加による a.の低下は有効であることが確立 されている ${ }^{9211)}$. 本研究においても塩漬時の食塩濃度と $\mathrm{a}_{\mathrm{w}}$ の間には相関関係が認められた．また $\mathrm{a}_{\mathrm{w}}$ 拉よび食塩 濃度とタンパク質の抽出性, とくにミオンンの抽出性に は同様の相関関係があると考古られる. 筋原線維タンパ ク質構成成分中約 50〜 55\%を占める ミオシンの 抽出性 が低下することの原因は，塩溶性タンパク質であるミオ シンが高濃度の食塩の添加と冷くんによる乾燥によって 食塩濃度が一段と上昇し, 筋原線維中の太いフィラィン 卜構造の変化に伴ら溶解現象を生じ,さらに $\mathrm{a}_{w}$ の低下 による自由水含量の低下とる関連して筋原線維構造その ものや，さらには筋原線維の集合体である能束をもちょ うど“のりつけ”にするような状態になることに起因す るかもしれない. $\mathrm{Mg}^{2+}-\mathrm{ATP}$ 添加により筋原線維は収 縮することが認められている12)，そこで塩漬や冷くん後 の朌原線維の生物機能の变化を収縮能を目安にして湘定 するため，筋肉を SSS-溶液中で通常のブレンダーにか けたところ，長期間塩漬を行った試料や冷くん後の試料 からは筋原線維の調製が困難であった。すなおちブレン ダー処理により筋原線維は小片化の傾向を示すが，長時 間のブレンダー処理によっても筋原線維どうしの側面会 合を解離することが困難であることが明らかになった。 ミオシンの溶解による“のりつけ”作用がこの現象に関 与している可能性が示唆される. ミオシンは生理的イオ ン強度ではフィラメント構造を呈しているがイオン強度 が上昇し $0.4 \sim 0.5$ モル以上の食塩濃度になると溶解す る、ちなみに $6 \%$ の食塩濃度はモル濃度に換算すると的 1 モルとなる.この濃度は十分にミオシンを溶解できる 
条件と考えられる. 生八厶製造の際塩漬終了時には肉中 の食塩濃度は $6 \%$ 近くになるが，ミオシンフィラメント の構造は規則正しく維持されている (Fig. 4-a) ことか ら, 筋肉中でミオシンが他のタンパク質成分とともに構 造を組んだ状熊ではその溶解性は異なるすの之考えられ る. しかしながら冷くんの進行に伴う食塩濃度の增加 と, $20^{\circ} \mathrm{C}$ 近傍での温度処理がミオンンフィラメントを 崩壊させるという結果を招くものと理解された (Fig. 4c). 一方，細いフィラメントを構成するアクチンやト口 ポミオシンはその抽出性にも大きな变化は認められずか なり安定に構造を保持していると想定された。

中野・安井 ${ }^{13) 14)}$ 水水分活性の变化に伴万精製 ミオシ ン, ミオンン B ならびに筋原線維 ATPase 活性の失活 について調べ，a范 0.4〜0.5ぐらいまではそれらの活 性は約 50\%をで失活することを認め,これらの変化はミ

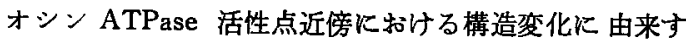
るものと報告している. 本研究の全筋肉でる $\mathrm{a}_{\mathrm{w}}$ の変動 に伴らミオシンの状態変化が顕著に認められ，ミオシン ATPase 活性の失活も想定された.

生ハム独自のテクスチャーは，塩漬と䩚燥・くん煙工 程によって生じた変化を 反映しているるのといえよう. なお,プロテフーゼの関わりの可能性も検討を要する重 要な事項であろう.

以上の結果，単に塩漬工程だけによる $\mathrm{a}_{w}$ の低下によ って得た中間水分肉はその食塩濃度にも依存するが，む との生肉飞近い状態飞復元が可能と思われる. しかし冷 くん煙の上らな条件による $\mathrm{a}_{w}$ の低下は，筋肉構造タン パク質に多大な状態変化を及注し復元は困難と示唆され る.

食塩はイオン結合により，砂糖は水素結合により水を 束縛する能力を持つ.ささらにンルビトールやグリセロー ルのように水酸基に富む物質もすぐれたとューィタタン 卜(保湿剂)である占). 今後さらにこれら添加物の組み 合せによる影晦を食肉成分の化学的変質を考慮しながら 検討する必要があると考えている。

\section{要䄪}

生八ムの製造工程中における食肉の状態変化ならびに 食塩濃度の变化による塩漬肉の状態変化について検討し た結果，次のことが明らかとなった。

（1）塩漬中に肉中の水分含量， $a_{w}$ 任低下し，それに伴 い食塩含有量は增加した。これらの変化は塩漬 3 日目ま でがとくに顕著であった．さらに塩漬後に実施された冷 くん処理はこれらの傾向を一段と強めた.
(2) タンパク質の抽出性ならびに抽出タンパク質成分 の分子種を SDS-PAGE により検討した結果, 生ハムの 製造工程中に扔ける水溶性タンパク質の抽出性に变化は 認められなかった。しかし㘯肉構造タンパク質は $\mathrm{a}_{\mathrm{w}}$ の 低下ならびにそれに伴う食塩含有量の増加と対俯して, 抽出量が低下する傾向を示し, 抽出量の低下は筋肉構造 タンパク質のらちミオシンに起因することが明らか炕な った. フクチンやトロポミオンンならびに $\alpha-$ フォチニ ンの抽出性には変化がなかった.

(3) 筀肉の微細構造の観察から，塩漬終了啳の試料は 筋原線維構造がよく保持されていた. しかし冷くん 4 日 目には太いフィラメントやZ 線の構造の崩壊が観察され た. 冷くん8日目ではさらにこの傾向が顕著となり， オシンより構成されている太いフィラメント構造の観察 は困難となった，一方，アクチンより構成されている細 いフィラメントはその構造を保持していた.

(4) 塩漬時における食塩添加量を変化させた結果, 食 塩添加量の增加に伴い、 $\mathrm{a}_{\mathrm{w}}$ は低下し, それと対応してミ オシンに由来する筋肉構造タンパク質の抽出量は低下し た.この結果から，生八ム製造工程中に括けるミオンン の状態变化も $a_{\mathrm{w}}$ 低下と食塩含有量の増加仁起因寸るも のと考えられる.

本研究は財団法人伊藤記念財団の研究助成を受けて行 ったものである．記して感詠の意を表します．

\section{文献}

1) ScotT, V.N. and Bernard, D. T.: J. Food Sci., 48, 552 (1983).

2) Holmquist, G. U, Walker, H. W. and Stahr, H. M.: J. Food Sci., 48, 778 (1983).

3) Silverman, G. J., Munsey, D. T., LeE, C. and Ebert, E.: J. Food Sci., 48, 1783 (1983).

4) Vaamonde, G., Chirife, J. and Scarmato, G.: J. Food Sci., 49, 296 (1984).

5) Nunes, R. V., Urbicain, M. J. and Rotstein, E.: Jood Sci., 50, 148 (1985).

6) Konizcko, E. S.: Handbook for Meat Chemists, Avery Publishing Group Inc. (1979).

7) Gornall, A. G., Bardawili, C. S. and David, M. M.: J. Biol. Chem., 177, 751 (1949).

8) Laemmli, U. K.: Nature, 227, 680 (1970).

9) Troller, J.A. and Christian, J. H. B.: Water Activity and Food, Academic Press, New York (1978).

10) Leistner, L. and RödeL, W.: Water Relations of Foods, p. 309, Academic Press, New York (1975). 
11) Ledward, D.A.: Developments in Meat Science2, 159, Applied Science Publishers, London, New York (1981).

12) Muguruma, M., Muguruma, Y. and Fukazawa, T.: J. Biochem., 88, 145 (1980).

13) Nakano, H. and Yasui, T.: Agric. Biol. Chem.,
40, 107 (1976).

14) Nakano, H. and Yasui, T.: Jpn. J. Zootech. Sci., 50, 161 (1979).

15) Sloan, A. E. and Labuza.: Food Prod. Dev., 9, 68 (1975).

(昭和 60 年 6 月 1 日受理) 